\title{
Correction: Impact of pregnancy and risk factors for ventricular arrhythmias in women with tetralogy of Fallot
}

Quattrone A, Lie $\mathrm{OH}$, Nestaas E, et al. Impact of pregnancy and risk factors for ventricular arrhythmias in women with tetralogy of Fallot. Open Heart 2021;8:e01400. doi: 10.1136/openhrt-2020-001400.

This article has been corrected since it was first published. The provenance and peer review statement has been included.

Open access This is an open access article distributed in accordance with the Creative Commons Attribution Non Commercial (CC BY-NC 4.0) license, which permits others to distribute, remix, adapt, build upon this work non-commercially, and license their derivative works on different terms, provided the original work is properly cited, appropriate credit is given, any changes made indicated, and the use is non-commercial. See: http://creativecommons.org/licenses/by-nc/4.0/.

(C) Author(s) (or their employer(s)) 2021. Re-use permitted under CC BY-NC. No commercial re-use. See rights and permissions. Published by BMJ.

Open Heart 2021;8:e001400corr1. doi:10.1136/openhrt-2020-001400corr1

A) Check for updates 